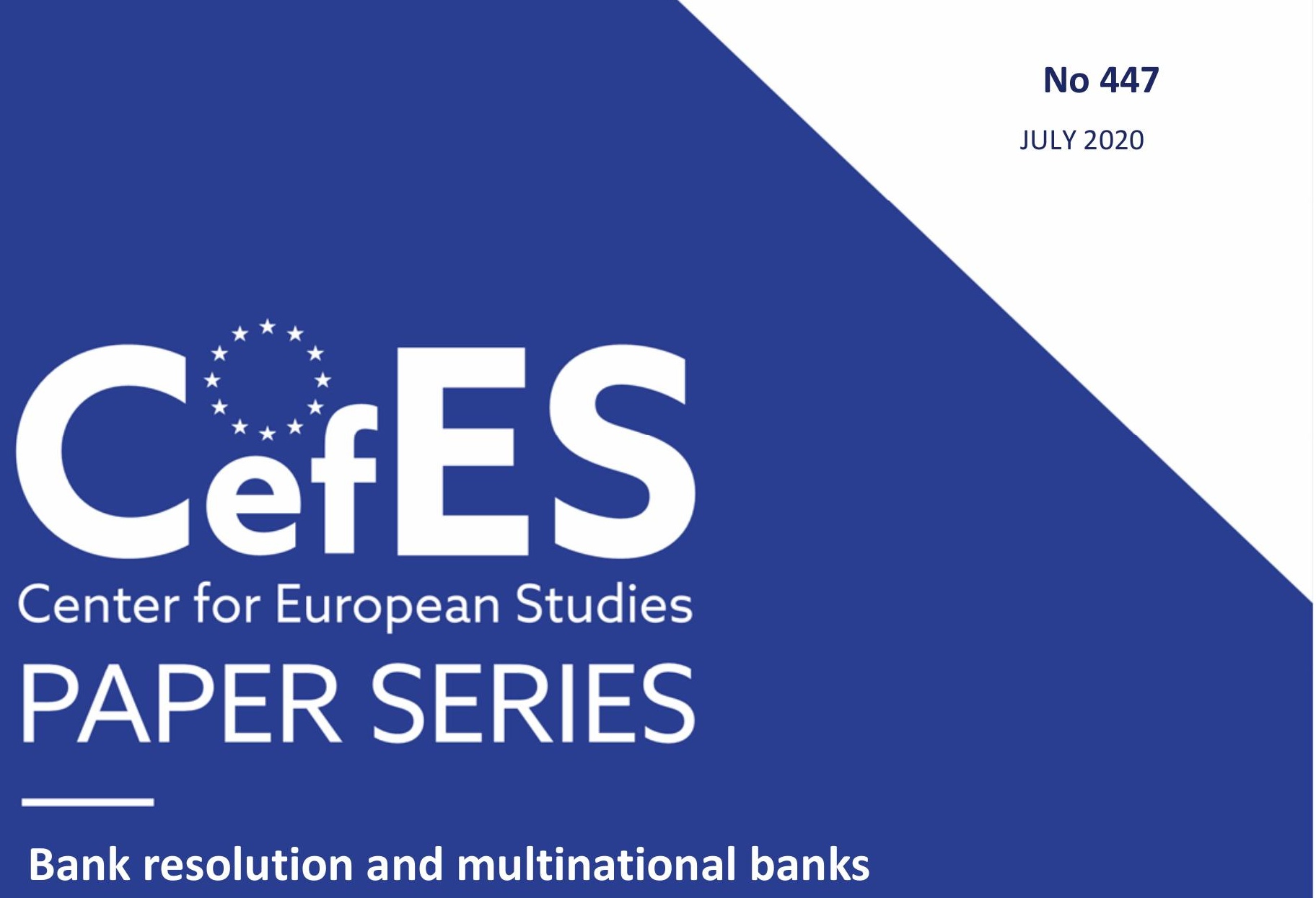

Vittoria Cerasi

and Stefano Montoli 


\title{
Bank resolution and multinational banks
}

\author{
Vittoria Cerasi* Stefano Montoli ${ }^{\dagger}$
}

July 14,2020

\begin{abstract}
This paper studies the impact of different resolution policies on the choice of banks to expand abroad. The regulator can choose to resolve banks through bail-in or bail-out or a combination of the two. The choice of the regulator affects the cost of funding of banks, endogenous in the model. We study the relative profitability of alternative bank corporate structures, either multinational (large and diversified) or domestic (small and non diversified) for different levels of public support. Our model allows us to identify the potential impact of the resolution policy on the structure of the banking system. Lower levels of public support increase the cost of funding for all banks, in line with recent empirical evidence. We show that a reduction in the level of public support (from bail-out to bail-in) induces banks to expand abroad in search for alternatives to save on their funding costs. Finally, we are able to identify the optimal resolution mix by taking into account the reaction of banks to the policy.
\end{abstract}

JEL classification: G21, G28.

Keywords: Bank regulation; bail-in; multinational banks; bank funding cost.

*Bicocca University, Department of Economics, Management and Statistics (DEMS) and Center for European Studies (CefES), Piazza dell'Ateneo Nuovo 1, 20126 Milano, Italy; e-mail: vittoria.cerasi@unimib.it

†Bicocca University and Center for European Studies (CefES). Email: s.montoli3@campus.unimib.it 


\section{Introduction}

The introduction of bail-in has been one of the major changes in banking regulation in the aftermath of the Global Financial Crisis. This new regulatory framework represents a significant improvement in the resolution of banks: however a comprehensive assessment of the impact of this new regulation requires understanding how banks will individually react to this new policy.

Recent empirical evidence has documented a general increase in the cost of funding for banks due to the greater alignment of the returns of new issues of unsecured bonds to bank risk. One possible solution for the individual bank could be to increase geographic diversification, by searching new lending opportunities in foreign countries, counterbalancing the greater funding cost with a reduction in credit risk. This paper proposes a simple framework to capture the impact of bail-in on funding costs and its implication for banks' incentive to expand abroad. The final goal is to identify the optimal policy taking into account the reaction of banks to the resolution framework.

The global financial crisis has shown how costly it has been to preserve the stability of the banking sector, in particular the resolution of troubled banks, when relying on public money. Indeed, while the various governments' interventions in support of banks has preserved the continuity in the provision of banking services, it has led to unprecedented costs for public finances in many developed countries. In Europe the Commission authorized total aids of EUR 3,892.6 billion for guarantees on liabilities between 2008 and 2014. An additional EUR 448 billion was spent on the public recapitalization of banks between 2008 and 2013 (see Lintner et al., 2016). In the US, after the failure of Lehman Brothers, several financial institutions received public support, mainly through the Troubled Asset Relief Programme, which accounted for $6 \%$ of the GDP in the fourth quarter of 2008 (Philippon and Salord, 2017). As a result, many countries, especially in Europe, experienced in 2010-12 severe sovereign debt crisis. The vicious circle, the so called "doom loop", between a rising sovereign debt and banking crises has been recently analyzed in Acharya, Drechsler, and Schnabl (2014). In addition, the anticipation of receiving ex-post public support in case of distress may weaken market discipline, leading ex-ante to excessive risk taking from bank: 1 . As a solution to the outlined problems, most developed economies have introduced formal bank resolutions and bail-in regimes (U.S. Dodd-Frank Act or the European Bank Recovery and Resolution Directive (BRRD)). According to this new regulation, in case of banks' distress creditors will directly absorb banks' losses, thus bearing part of the costs of restoring the bank. The BRRD allows for public support to failing institutions, when this is required

\footnotetext{
${ }^{1}$ See Dell'Ariccia et al. (2018) and the references therein for empirical evidence.
} 
to preserve financial stability, but only after shareholders and creditors have contributed with their own funds up to $8 \%$ of the bank liabilities. The objective of the new regulatory framework is to minimize the cost of banks recovery for taxpayers and to improve the efficiency of the resolution process. Also, turning unsecured debt into bailinable debt should increase the level of monitoring by creditors, thereby reducing banks' risk-shifting attitude.

Recent empirical evidence, however, has shown that the increased risk of exposure to losses by creditors has increased the cost of funding for banks. In particular, Schafer, Schnabel, and Weder (2016) have shown that shares prices movements signal that the expectation of bail-in affects future bank returns indirectly through the effect on [increased] funding costs. Crespi, Giacomini, and Mascia (2019), Cutura (2018), Giuliana (2019), Lewrick, Garralda, and Turner (2019) document an increase in spread between bailinable and non bailinable bonds for European banks. Furthermore, the spreads appear to be sensitive to banks' riskiness, thus supporting the hypothesis that bail-in induced greater market discipline.

We elaborate on the strategic reaction of banks to the new resolution policy, by focusing on the increased sensitivity of funding costs to bank risk. In particular, we unveil a relation between bail-in and geographic diversification. Indeed, while the bail-in regime induces investors to require a risk premium for holding bank bonds, risk can be diversified away by banks through expansion abroad. Levine, Lin, and Xie (2019) demonstrate that geographic diversification is linked to lower costs for interest bearing liabilities. Aldasoro, Hardy, and Jager (2020) also support the hypothesis that geographic complexity reduce banks' exposure to local shocks, thanks to an increased diversification.

Our paper provides a theoretical framework where banks differ according to their cost of monitoring projects and funding costs are determined endogenously. Banks can choose to operate domestically, lending in one single country, or as multinational bank, lending in two countries. Multinational banks are bigger and, thanks to the diversification of their portfolio of loans, can allocate resources across units to reduce their exposure to credit risk. Indeed, credit losses can be shared across branches and resources from the branch operating in one country can be used to cover potential shortfalls in the other country.

In case banks are not able to meet their obligations, due to large credit losses, a group of bondholders may be subject to haircut on the face value of their bonds, while the remaining group is reimbursed using public money. In the model, we allow for a resolution policy ranging from full bail-out to full bail-in. The focus of our analysis is to understand how the resolution policy impacts on the endogenous funding cost of banks. 
The novelty of our paper is to show that bail-in, not only induces a rise in the overall funding cost for banks, but it also stimulates banks to expand abroad in search for gains from diversification. This implies that moving from bail-out to bail-in, the number of viable domestic banks shrinks, although this effect can be more than compensated by the entry of new multinational banks.

The key mechanism is the following. When there is a positive probability of bailout, the risk entailed by a portfolio of loans in a bank is not perfectly priced, due to the implicit guarantee of a public subsidy: this creates a wedge in expected funding costs between domestic and multinational banks. In other words, the choice to expand abroad reduces the value of the public guarantee, since multinational banks by being more diversified are less riskier and will benefit less from the bailout. This is a perverse effect of diversification for a multinational bank. Domestic banks on the contrary fully benefit from bailout and also inefficient firms become viable. When the resolution regime moves from bailout to bail-in, since the price of the bond correctly reflects the true risk of the bank, multinational banks enjoy lower funding costs due to the diversification of credit risks. To conclude, when we rule out the possibility of public support, since multinational banks have a lower risk of insolvency, they benefit of a reduced risk premium when issuing bail-in-able debt, thus becoming relatively more profitable.

In determining the optimal policy, the regulator anticipates the reaction of the banking sector. As such, the trade-off that allows for the identification of the optimal level of public support is the following: a reduction in the level of public support increases bank funding cost for all type of banks, thus increasing the region where domestic banks are insolvent. On the other hand it increases the relative profitability of multinational banks. The social benefit of multinational banks is twofold: first the supply of credit is expanded due to the substitution of insolvent domestic banks with larger multinational banks. Second, thanks to their diversification, multinational banks are less risky. The trade-off between increased failure of domestic banks and new entry of multinational banks allows us to identify the level of public support that should be allowed to troubled banks in the choice of the optimal resolution regime.

Relation with the literature. Our paper contributes to the literature on the optimal design of banks' resolution policy. Within the intense debate over the reforms that followed the Great Financial Crisis, a strand of literature has focused on the pros and cons of the different policies to deal with troubled banks. In particular, Avgouleas and Goodhart (2015) argue that, while bail-in induces better creditors monitoring and reduces the level of moral hazard entailed in public interventions, it also leads to higher funding costs for banks and it might amplify banks' crisis in case of systemic shocks. In a similar vein, Dewatripont (2014) 
argues that bail-in can be detrimental to financial stability, as it might induce bank runs, especially if banks don't hold enough long-term loss absorbency capacity to prevent panic from spreading among short-term claim-holders. Moreover, bailout might help protecting the "average bank" in case of a systemic crisis, leaving only the worst banks out of the market. This observation is in line with the optimal policy proposed in our analysis. Indeed we argue that bail-in creates an incentive for more efficient banks to expand abroad, while the least efficient banks are left out. Nevertheless, a certain level of public support is desirable to prevent the failure of a sub optimally large number of banks. Dell'Ariccia et al. (2018) review the empirical literature on the nexus between bailout and moral hazard by banks and on the systemic spillovers of bail-in. Furthermore, the authors introduce a theoretical model to account for the costs associated with bail-in and bail-out, showing that the optimal policy mix crucially depends on the relevance of systemic spillovers of bail-in. Although all those papers emphasize the great improvement in the adoption of bail-in, they argue in favor of maintaining some degree of public intervention, especially when needed to preserve financial stability.

Within the debate on the optimal mix between bail-out and bail-in, Walther and White (2019) and Pandolfi (2018) show with models capturing different features of a debt-overhang problem for the banker, that it is optimal to complement bail-in with bail-out to reduce deadweight social losses. While in Walther and White (2019) bail-in consists in writing-off long-term debt and ameliorates the debt-overhang problem, the discretion left to the regulator to call for bail-in releases a bad signal to investors who refuse to roll-over short-term debt. To avoid an aggressive bail-in for banks that do not deserve it in some states of the world, they call for some degree of bail-out. In Pandolfi (2018) bail-in is defined as conversion of debt into equity and it implies dilution of incentives to monitor loans for the insiders of the bank. In addition, the higher funding cost required by bondholders as a consequence of expectation of bail-in, reinforces the debt-overhang problem of the banker. To avoid this, bailout could be retrieved in some instances. Both papers analyze the consequences of bail-in on the cost of funding for banks and on the incentives of the banker, calling for a mix of bail-in and bail-out. We also elaborate on the endogenous rise of funding costs induced by the bail-in and solve for the optimal resolution policy mix. However we focus on the diversification choice of the banker and show that bail-in is the optimal solution when considering the impact on the structure of the banking industry, although it implies exit of the least efficient banks. If this involves a social cost due to the disruption of payment services, there is scope to restore some degree of bailout. 
The nexus between the resolution policy and banks' choice to expand abroad, in presence of endogenously determined funding costs, is also studied in Luciano and Wihlborg (2018). While allowing for a richer characterization of banks' organizational structure (e.g. different forms of foreign of representation are considered), their focus lies on the value of the different organizational structures and their implications for systemic risk. The different objectives of the banks (the maximization of value) and the regulator (the minimization of systemic risk) gives rise to a conflict of interest between the two parties. In this sense, our analysis is complementary, in the sense that it enriches the interaction between the banks and a benevolent regulator. Indeed, our simpler framework allows for the aggregation of banks' organizational choices, which in turn is key for the identification of an optimal resolution policy.

Our analysis builds also on the empirical evidence of the adoption of the new resolution policy on bank funding costs. Schfer et al. (2016) document a decrease in bank returns following a bail-in. The authors comment this evidence as suggestive of an expected increase in funding costs due to the reduced likelihood of future public support. Crespi, Giacomini and Mascia (2019) find evidence of an increase in the spread at the time of their issuance of bail-in-able bonds compared to non bail-in-able bonds for Italian banks. This effect became significantly relevant after Italian authorities decided to resolve four small banks in November 2015. Cutura (2018) and Giuliana (2019) also find similar evidence, finding an average 10 basis points bail-in premium on bail-in-able bonds. Lewrick, Garralda and Turner (2019) also identify a bail-in risk premium for bail-in-able bonds issued globally. This literature documents how the introduction of the bail-in regime was deemed credible by investors and increased banks' market discipline. Indeed, the increase in funding costs also appears to depend on banks' riskiness. As such, this evidence also support our result that a switch from bail-in to bail-out increases the elasticity of funding costs to the risk of the bank's portfolio. In line with this, our work also relates to the evidence in Levine, Lin and Xie (2019) which shows that geographic expansion reduces the costs of interest-bearing liabilities thanks to the benefits of diversification. This evidence is further supported by the observation that the drop in funding costs is more pronounced when the bank expands in regions whose economy is less correlated to the region of origin of the bank. Further studies directly addressed the impact of banks' geographic expansion on their riskiness. Deng and Elyasiani (2008) and Goetz, Laeven and Levine (2016) analyse geographic diversification in the US banking industry, showing that geographic expansion lowers risk thanks to a reduced exposure to idiosyncratic shocks. Fang and van Lelyveld (2014) use a sample of some of the world's largest banking groups to show that geographic diversification helps mitigating credit risk, although the magnitude of the effect varies significantly across different banking groups. In particular the benefits of 


\begin{tabular}{|c|c|c|c|}
\hline$t=0$ & $\begin{array}{c}t=1 / 2 \\
1\end{array}$ & $t=1$ & $t=2$ \\
\hline - Regulator sets $\alpha$. & $\begin{array}{l}\text { - Monitoring cost } c \text { is } \\
\text { privately observed. }\end{array}$ & $\begin{array}{l}\text { - Banks choose to be } \\
\text { domestic or } \\
\text { multinational; } \\
\text { - Investors fund the } \\
\text { bank. }\end{array}$ & $\begin{array}{l}\text { - Projects' returns } \\
\text { realize } \\
\text { and are divided } \\
\text { among stakeholders. }\end{array}$ \\
\hline
\end{tabular}

Fig. 1. Timeline of the game

diversification appear to be dependent on the level of synchronization of the business cycle in different countries. Finally, Faia, Ottaviano and Sanchez (2017) and Duijm and Schoenmaker (2020) provide empirical evidence on the negative link between geographic diversification and riskiness for European banks. They confirm that diversification is beneficial also when international rather than intra-national, and more so when business cycles of the different countries where the bank is located are less synchronized. Overall, this literature provides support to our observation that banks' decision to expand abroad is beneficial to their risk profile thanks to an increased resilience to idiosyncratic shocks, and this is turn reflected on banks' funding costs.

The rest of the paper is organized as follows: section 2 sets up the model, section 3 describes the effect of different levels of public support, section 4 analyzes the optimal resolution policy and section 5 concludes.

\section{The Model}

Consider an economy populated by banks, entrepreneurs with productive projects and investors. All agents are risk neutral.

Projects. Each productive project yields a return $R$ with probability $p \in(0.5,1), 0$ otherwise.

Banks. Banks have no capital and finance risky projects by issuing bonds. Banks monitor projects at a $\operatorname{cost} c$. There is heterogeneity at bank level, that is, each bank is characterized by a specific cost of monitoring $c$ distributed according to a uniform distribution on $\left[0, c_{\text {Max }}\right]$. Investors. There is an infinite number of investors with one unit of capital each. Investors can choose between bonds issued by banks and an alternative investment yielding a safe return equal to 1 . Capital markets are perfectly competitive. 
Resolution policy. Assume bondholders might benefit of a public support in the form of a transfer in case of bank failure: a fraction $\alpha \in[0,1]$ of bondholders is protected, while the remaining fraction suffer losses in case of bank failure. As $\alpha$ increases, we move from the case of complete bail-in $(\alpha=0)$ to the case of full bail-out $(\alpha=1)$.

Timing. The timing of the game is the following: first the regulator announces the fraction of bondholders that will be compensated within the program of resolution of the bank with public money, that is $\alpha$; then, each bank observes its specific realization of the cost of monitoring $c$; investors set the rate at which they are ready to fund each bank. Finally, returns of the lending activity realize and stakeholders are repaid. The timing of the game is represented in Figure 1. The game is solved backward.

\subsection{Endogenous funding cost}

The objective is to determine endogenously the cost of funding for the bank when there is a resolution policy in place. For simplicity we assume that the bank retains the whole return $R$ from the productive projects it finances. In this case, the expected profit of the bank is:

$$
p \times \max \left\{R-r_{D}, 0\right\}-\frac{c}{2}
$$

From equation (1) we see that ex-ante the bank is solvent whenever $R>r_{D}$, that is, only in case the return of the successful project is sufficiently high to repay bondholders. In case of failure of the project, due to limited liability, the bank is insolvent and does not repay bondholders. We assume that each project has a positive NPV, that is:

$$
R>\frac{1}{p}>1
$$

with the limitation that $p \in(0.5,1)$, namely $\frac{1}{p}<2$.

Due to competition in capital markets, investors expect to receive just the opportunity cost of their initial investment, set equal to the return on the safe asset. Investors anticipate to be repaid the face value $r_{D}$ when the bank is solvent; when the bank is insolvent, since investors observe the resolution policy, they anticipate that a fraction $\alpha$ of bondholders will recover at least the opportunity cost of their investment through injection of public money.

The investors' rationality condition is:

$$
p r_{D}+(1-p) \alpha=r_{D}-E S_{1}(\alpha)=1
$$

where $E S_{1}(\alpha) \equiv(1-p)\left(r_{D}-\alpha\right)$ are the ex-post expected shortfalls that bondholders antic- 
ipate to suffer. In equilibrium, the cost of funding for a domestic bank is:

$$
r_{D}(\alpha)=\frac{1-\alpha}{p}+\alpha=1
$$

Notice that the cost of funding decreases with $\alpha$ and reaches its minimum, i.e. $r_{D}=1$, when there is full bail-out $(\alpha=1)$. As a matter of fact, the derivative of (3) w.r.t. $\alpha$ is the "odd ratio" of the event default, namely the probability that the domestic bank does not repay bondholders over the probability that it repays them:

$$
\frac{\partial r_{D}(\alpha)}{\partial \alpha}=-\frac{(1-p)}{p}<0
$$

As the expectation of bail-out increases, the interest rate required by bondholders falls, as the probability of having to face ex-post expected shortfalls reduces. This result is in line with the empirical evidence finding that after the introduction of bail-in the cost of funding has risen for banks as more creditors have started to expect an increasing probability of suffering an haircut on the face value of their bonds in case of bank failure. In case of full bail-out bondholders are ready to accept the minimum interest rate, that is, the return on perfectly insured deposits.

Substituting $r_{D}$ into (1), we derive the expected profit of the bank at the equilibrium:

$$
E\left[\Pi_{D}(\alpha)\right]=(p R-1)+\alpha(1-p)-\frac{c}{2}
$$

where the first term represents the NPV of the productive project, the second is the amount of public money injected in case of bank failure and the third is the cost of monitoring. The bank pays $r_{D}$ every time the project succeeds. As $\alpha$ increases $r_{D}$ decreases, implying savings for the bank on the amount of money owned to its creditors. With bail-out the public money replaces the private money with which the bank has to repay bondholders, reducing the cost of funding for the bank. These savings become an extra-profit $\alpha(1-p)$ for the bank.

The bank is viable, that is, its profit is non-negative, when the monitoring cost is sufficiently low:

$$
c \leq c_{D}(\alpha) \equiv 2(p R-1)+2 \alpha(1-p)
$$

Notice that the threshold $c_{D}(\alpha)$ is increasing in $\alpha$ since $c_{D}^{\prime}(\alpha)=2(1-p)>0$. Indeed, greater public support, increases the slack, inducing even less efficient banks to become viable. 


\subsection{Multinational banks}

Consider now the strategy of a bank willing to increase its scale of lending. Assume that the bank faces no opportunities in the home country and thus has necessarily to expand abroad. In our simple model we imagine a bank financing two projects, one project in the home country and the other in the foreign country. Although returning the same return $R$ the two projects are uncorrelated, thus giving rise to benefits from diversification. Assume that all banks in the economy face this choice between operating in the home country, i.e. to be domestic, or expanding abroad, thus becoming a multi-national bank (MNB).

When a bank chooses to be domestic it raises one unit of debt and finances one project in the home country. The alternative is to become a MNB, thus raising two units of debt to finance two projects, one in each country. Expanding abroad means opening a branch, that is, a foreign office of the home bank. To capture the idea of an increasing cost of monitoring uncorrelated projects and more in general the costs of running two units in two different countries, we assume that MNBs face twice the cost of monitoring one project by a domestic bank, since lending abroad implies overcoming legal and cultural barriers.

Considering that both the domestic and the foreign units are responsible for each other's losses, we can write the consolidated profits as:

$$
2 p^{2} \times \max \left\{R-r_{M}, 0\right\}+2 p(1-p) \times \max \left\{R-2 r_{M}, 0\right\}-c
$$

The central term in the profit refers to the case where one project is successful and the other one fails (with probability $p(1-p)$ ): we thus have to distinguish between two cases:

- case (a), when $r_{M} \leq \frac{R}{2}$ : the return from the successful project is enough to repay the promised rate to bondholders;

- case (b), when $r_{M}>\frac{R}{2}$ : what is returned by the successful project is not enough to refund all bondholders; in this case $(1-\alpha)$ bondholders receive $\frac{R}{2}$, while another fraction $\alpha$ is bailed-out and receive 1 unit as public support.

In the rest of the paper we will develop the analysis assuming

$$
2 \leq R \leq \frac{2}{p(2-p)}
$$

which refers to case (a), as shown in Lemma A.1 (see the Appendix). We leave the full analysis of case (b), in the Appendix, since the results are similar. 
The investors' participation constraint is:

$$
p^{2} r_{M}+2 p(1-p) r_{M}+(1-p)^{2} \alpha=1
$$

The first term is when both projects succeed with probability $p^{2}$ and bondholders receive the promised rate $r_{M}$; the second term is when one project succeeds and the other fails, but the revenue $R / 2$ is enough to repay $r_{M}$ to each bondholders; the last term is when both projects fail with probability $(1-p)^{2}$ and a fraction $\alpha$ of bondholders is bailed out and receive 1 unit of public money.

The expected shortfalls for bondholders are:

$$
E S_{2}^{a}(\alpha)=(1-p)^{2}\left(r_{M}-\alpha\right)
$$

since bondholders expect to suffer ex-post losses equal to $\left(r_{M}-\alpha\right)$ in case the MNB fails. The overall cost of funding for a MNB, solving equation (8) for $r_{M}$, can thus be written as:

$$
r_{M}^{a}(\alpha)=\frac{1-\alpha}{p(2-p)}+\alpha
$$

Notice that the cost of funding decreases with $\alpha$ and reaches its minimum, i.e. $r_{M}^{a}=1$, when there is full bail-out $(\alpha=1)$. As a matter of fact, the derivative of 10$)$ w.r.t. $\alpha$ is the "odd ratio" of the event default, namely the probability that the MNB does not repay bondholders on the probability that it repays them:

$$
\frac{\partial r_{M}^{a}(\alpha)}{\partial \alpha}=-\frac{(1-p)^{2}}{1-(1-p)^{2}}<0
$$

As the expectation of bail-out increases, the interest rate required by bondholders falls. The probability of having to face a default ex-post reduces with $\alpha$, similarly to the case of a domestic bank. However an increase in bail-out reduces the odd ratio more for a domestic bank compared to a MNB. This is due to the fact that, with some degree of bail-in, the probability that a domestic bank defaults is larger compared to a MNB, since a MNB gains from diversification of its portfolio of loans. In other words, bail-out benefits more bondholders of a domestic bank compared to those of a MNB, since the MNB repays them more often with the greater expected revenue from its diversified portfolio of loans.

We can now write the expected profits of the bank, substituting the bond rate 100 into (7):

$$
E\left[\Pi_{M}^{a}(\alpha)\right]=c_{D}(\alpha)-2 \alpha p(1-p)-c
$$


using the definition of the threshold for the domestic bank in (6). Based on what derived so far, we have that a MNB is profitable only when the monitoring cost is below a specific threshold, that is:

$$
c \leq c_{M}(\alpha) \equiv c_{D}(\alpha)-2 \alpha p(1-p)
$$

It is immediate to see that $c_{M}(\alpha)$ is smaller than $c_{D}(\alpha)$, in other words the threshold for a MNB must be smaller than that for a domestic bank. The larger costs of monitoring of a MNB overweights the benefits from diversification. A MNB must be more efficient compared to a domestic bank in order to be viable. Notice that also for a MNB the threshold to be viable increases with $\alpha$.

\section{Resolution and banking structure}

Each bank is identified by a specific monitoring cost $c$. According to the region where this specific $c$ lies, the bank may be viable as a domestic or multinational bank. However the relative profitability of the two type of banks is affected by the particular resolution policy, in our simple model defined by $\alpha$. In this section we analyze how the resolution policy changes the structure of the banking system, namely the fraction of MNBs over domestic banks. We first consider the case of full bail-out $(\alpha=1)$ and then look at the case of complete bail-in $(\alpha=0)$.

\subsection{Full bail-out $(\alpha=1)$}

In this section we consider the case where all investors are protected by public guarantees in case of bank failure, that is the case with $\alpha=1$. In this case the bond rate is equal to 1 for both types of bank, as $r_{D}(1)=r_{M}^{a}(1)=1$. Exploiting equation (6) when $\alpha=1$, the domestic bank is viable when:

$$
c \leq c_{D}(1) \equiv 2(p R-1)+2(1-p)
$$

while from equation 13 when $\alpha=1$, a MNB is viable whenever:

$$
c \leq c_{M}(1) \equiv c_{D}(1)-2 p(1-p)<c_{D}(1)
$$

In addition we derive the condition for which a MNB is more profitable than a domestic bank:

$$
c \leq c_{\Pi}(1) \equiv c_{D}(1)-4 p(1-p)<c_{M}(1)
$$




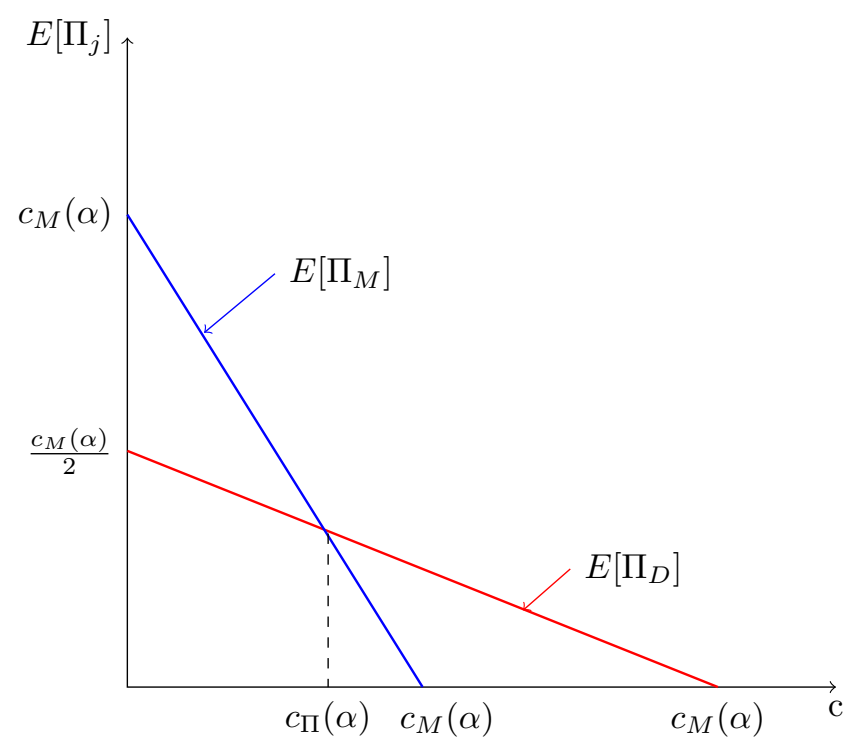

Fig. 2. Expected profits with $\alpha=1$.

In the case of full bail-out, we can summarize the results in the following proposition:

Proposition 1. Assuming that each bank's monitoring cost is a specific realization from the uniform distribution on $\left[0, c_{M a x}\right]$, that project return is $R \in\left[2, \frac{2}{p(2-p)}\right]$ with probability of success $p \in(0.5,1)$ and that returns are independent across countries, we have in the case of full bail-out $(\alpha=1)$ that:

(i) the minimum monitoring cost that guarantees positive expected profit is larger for a domestic bank compared to a $M N B$, that is $c_{D}(1)>c_{M}(1)$;

(ii) a MNB has positive profits for values of $c$ in the interval $\left(c_{\Pi}(1), c_{M}(1)\right)$, although the domestic bank is more profitable;

(iii) the expected profit of a MNB is higher compared to that of a domestic bank whenever $c<c_{\Pi}(1)$.

Results at points $(i)$ and $(i i)$ are explained by the fact that, for each unit lent, the domestic bank saves on funding costs since it pays the same face value (=safe rate) to its bondholders, but with a lower probability ( $p$ instead of $p(2-p)$ for a MNB): hence it can stands a lower degree of efficiency in monitoring. Result at point (iii) is explained by the smaller size of a domestic bank compared to a MNB: for low enough monitoring cost, the MNB has expected returns twice as larger as those of a domestic bank. When the size effect dominates the difference in monitoring costs, the profit of the MNB dominates that of the domestic bank. 


\subsection{Complete bail-in $(\alpha=0)$}

We consider now the relative profitability of banks when public support is absent, that is, $\alpha=0$. In this case investors require a return rate that fully incorporates the risk of the different business models. In particular, we have:

$$
r_{M}^{a}(0)=\frac{1}{p(2-p)}<r_{D}(0)=\frac{1}{p}
$$

Result in (17) follows from the diversification of the portfolio: bondholders in the MNB are repaid with a higher probability and thus accept a lower return rate. Now we can derive the expected profits of the different bank models.

In this case notice that all thresholds collapse to the same value:

$$
c_{D}(0)=c_{M}(0)=c_{\Pi}(0)
$$

Results in the case of $\alpha=0$ can be summarized in the following proposition:

Proposition 2. Assuming that each bank's monitoring cost is a specific realization from the uniform distribution on $\left[0, c_{\text {Max }}\right]$, that project return $R \in\left[2, \frac{2}{p(2-p)}\right]$ occurs with probability of success $p \in(0.5,1)$ and that returns are independent across countries, we have in the case of bail-in $(\alpha=0)$ that:

(i) the minimum monitoring cost that guarantees positive expected profit for the two types of banks is the same;

(ii) when $c<c_{D}(0)$ the expected profit of a MNB is always higher than that of a domestic bank, implying that in the regions where the domestic bank is viable, the MNB is always more profitable.

Proof. Since the thresholds coincide for the two types of banks, both domestic and MNB banks are viable for the same set of realizations of $c$. The profit of the domestic bank is $E\left[\Pi_{D}(0)\right]=\max \left\{(p R-1)-\frac{c}{2}, 0\right\}$ while for a MNB is $E\left[\Pi_{M}^{a}(0)\right]=\max \{2(p R-1)-c, 0\}$. For $c \geq c_{D}(0)$, it is easy to prove that the profit of a MNB is larger than that of a domestic bank.

Figure 3 shows the results in proposition 2 .

To understand the result in point $(i)$ consider that for every unit of return, banks pay the same costs, whatever the structure they choose. This is so first because they pay different bond rates, but also since they repay creditors with different probabilities: with $\alpha=0$, the riskiness of bonds is perfectly priced, therefore the two effects perfectly offset each others. 


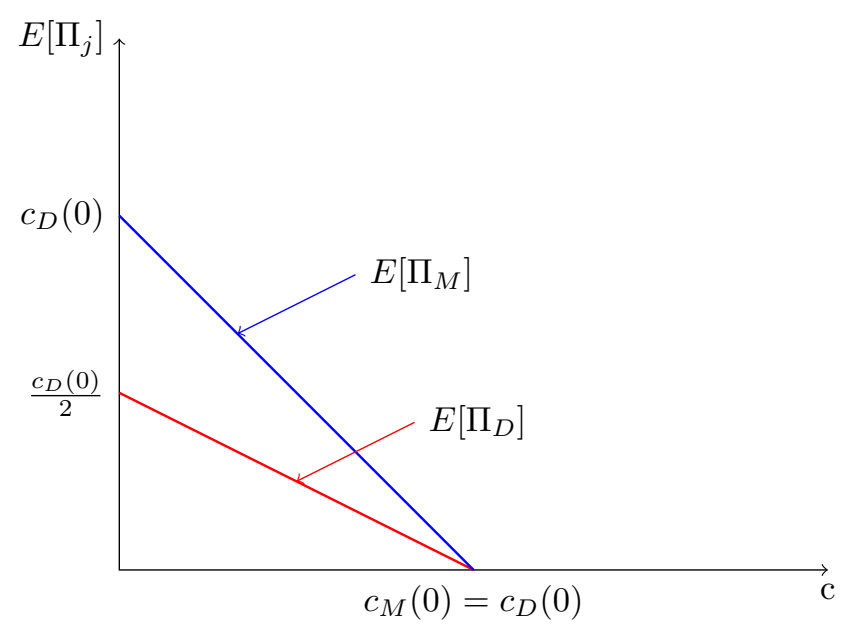

Fig. 3. Expected profits with $\alpha=0$.

Second, they face the same monitoring cost per unit lent. The result at point (ii) follows from the result at point $(i)$ since a MNB has the double the size of a domestic bank: whenever $c$ is sufficiently low compared to the NPV of the project, i.e. $c<c_{D}(0)$, the expected profit of a MNB is the double compared to that of a domestic bank.

\subsection{Comparative Statics}

In this section we analyze the results obtained in sections 3.1 and 3.2 for different values of $\alpha$. We recall here the expression of the different thresholds. First of all, the threshold on $c$ for a domestic bank to be viable is:

$$
c_{D}(\alpha) \equiv 2(p R-1)+2 \alpha(1-p)
$$

while for a MNB:

$$
\left\{\begin{array}{l}
c_{\Pi}(\alpha) \equiv c_{D}(\alpha)-4 \alpha p(1-p) \\
c_{M}(\alpha) \equiv c_{D}(\alpha)-2 \alpha p(1-p)
\end{array}\right.
$$

We can illustrate the equilibrium outcome of the choice of banks in terms of the different realizations of $c$ in Figure 3.

\section{Figure 3 - here}

The first effect relates to the change of the thresholds. In particular, for a generic level of $\alpha \in[0,1]$ the impact on the thresholds of $c$ for a MNB is:

$$
\frac{\partial c_{M}(\alpha)}{\partial \alpha}=\frac{\partial c_{D}(\alpha)}{\partial \alpha}-2 p(1-p)<\frac{\partial c_{D}(\alpha)}{\partial \alpha}=2(1-p)
$$


From (21) we see that a rise in the level of $\alpha$ (moving from bail-in to bail-out) produces an increase in the thresholds, which is greater for the domestic bank than for the MNB. This is in line with the results obtained in the previous sections: with $\alpha=1$ (bail-out) we have in proposition 1 that $c_{M}(1)<c_{D}(1)$, while with $\alpha=0$ (bail-in) all the thresholds collapse to the same value. Indeed, with $\alpha=1$ the bond rate is equal to 1 for both types of banks. However, the MNB bank repays bondholders with a higher probability, hence the funding cost per unit lent is higher compared to that of a domestic bank. As $\alpha$ decreases (from bail-out to bail-in), the bond rate increasingly prices the risk entailed by each type of bank. Due to the double direction in which cross subsidies can go in the case of a MNB, bondholders will be repaid with the highest probability and thus the bond rate for a MNB will increase relatively less. When $\alpha=0$ the expected funding cost per unit lent is the same for all bank types since the bond rate fully reflects the different levels of risk. In this case the differences in the funding costs are exactly offset by the different probabilities with which the bond is repaid.

The second effect we need to consider is the effect on the profitability of banks. This effect is partly due to the different size of the two banks. In particular, on the one hand, the MNB earns the double of the revenues of a domestic bank. On the other hand, whenever $\alpha \neq 0$, the MNB pays a funding cost that is less than the double that of a domestic bank. Given the presence of public funds, the bond rates don't full reflect the risk entailed by the two business models. The domestic bank pays on average a lower bond rate, which is more than offset by the higher probability of repayment. In addition, the MNB faces higher operating costs. Overall the MNB earns higher expected profits when $\mathrm{R}$ is sufficiently high for the difference in revenues to overcome the difference in costs.

The following proposition generalizes the results in Propositions 1 and 2 .

Proposition 3. Assuming that each bank's monitoring cost is a specific realization drawn from the uniform distribution $\left[0, c_{M a x}\right]$, and that project return $R \in\left[2, \frac{2}{p(2-p)}\right]$ occurs with probability of success $p \in(0.5,1)$ and that returns are independent across countries, we have that for any $\alpha \in[0,1]$ :

(i) the MNB is more profitable than the domestic bank when $c<c_{\Pi}(\alpha)$;

(ii) there exists a subset of realizations of $c$ where the domestic bank is the most profitable, that is when $c_{\Pi}(\alpha)<c<c_{D}(\alpha)$ for any $\alpha>0$;

(iii) as the degree of public support $\alpha$ decreases, the MNB becomes more profitable relatively to domestic banks; in fact, as $\alpha$ decreases, the thresholds $c_{\Pi}(\alpha)$ decrease less compared to $c_{D}(\alpha)$ : hence the mass of MNB increases compared to that of domestic banks. 


\section{Optimal Resolution Policy}

In this section we analyze the optimal resolution policy considering the outcome in terms of banks' structure. In particular, the analysis in section 3 shows that the structure of the banking sector is a function of the resolution policy announced by the regulator. Thus, in defining the optimal policy, the regulator will have to consider the implications on the structure of the banking system. At this point we need to focus on two effects:

- First, the level of $\alpha$ will influence the mass of viable banks, that is those that will not be able to raise funds and forced to close. This set of banks is defined by the threshold $c_{D}(\alpha)$.

- Second, it will influence the structure of banks that will find it profitable to switch from MNB to domestic, defined by the threshold $c_{\Pi}(\alpha)$.

To capture in reduced form the negative effect of banks' closure, we assume that the contribute of banks to the social welfare goes beyond its profits, and also includes the provision of social relevant services, i.e. payment services and the production of information on borrowers. This contribution is captured by the parameter $\gamma>0$. We also assume that MNBs gives a double service, both in the domestic and the foreign country. This is to capture the fact that, when the regulator chooses a lower $\alpha$ (moving from a regime of bail-out to bail-in), the reduced provision of services caused by banks' closure can be substituted to some extent by the entry in the market of new MNBs.

Also, the reduction in the amount of loans caused by the closure of domestic banks, can be substituted by the increase in the amount of loans provided by MNBs, which are also better in picking profitable investment projects, given their ability to diversify risks.

We now introduce the objective function of the regulator. In particular, we assume that the regulator maximizes the expected social welfare given by the sum of banks' profits, savings in taxpayers' money $\left.\right|^{2}$ plus the social value of the activity of each domestic bank:

$$
E^{D}[W]=E\left[\Pi_{D}(\alpha)\right]+\gamma-\alpha(1-p)=p R-1-\frac{c}{2}+\gamma
$$

whereas the contribution of each MNB to social welfare is 3

$$
E^{M}[W]=E\left[\Pi_{M}(\alpha)\right]+2 \gamma-2 \alpha(1-p)^{2}=2\left[p R-1-\frac{c}{2}+\gamma\right]=2 E^{D}[W]
$$

The social contribution of MNBs is twice that of domestic banks due to the size effect. Given this specification of the social welfare function, for a given banking structure, the resolution

\footnotetext{
${ }^{2}$ The model can be extended to include a social cost of distortionary taxation.

${ }^{3}$ Here we solve case (a), while we derive a similar result for case (b) in the Appendix
} 


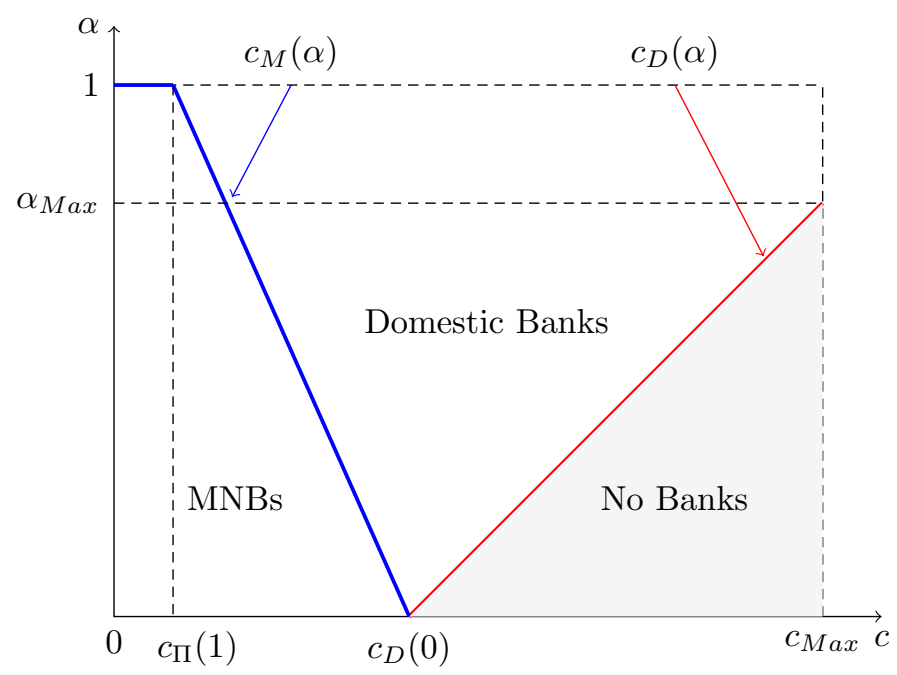

Fig. 4. Resolution policy: banks' business models and welfare.

policy chosen by the regulator has no effects on the contribution of each bank to the social welfare, i.e. $\frac{\partial E^{j}[W]}{\partial \alpha}=0$ for $j=\{D, M\}$ as can be seen from 22 and 23 . However it changes the intervals of the regions where domestic and MNBs banks exist. In particular, MNBs will exist for $c$ in the interval $\left[0, c_{\Pi}(\alpha)\right]$ while domestic banks in the interval $\left[c_{\Pi}(\alpha), c_{D}(\alpha)\right]$, where:

- $c_{D}(\alpha)=2(p R-1)+2 \alpha(1-p)$;

- $c_{\Pi}(\alpha)=c_{D}(\alpha)-4 \alpha p(1-p)$.

with $\frac{\partial c_{D}(\alpha)}{\partial \alpha}>0$ and $\frac{\partial c_{\Pi}(\alpha)}{\partial \alpha}<0$, implying that as the regulator increases $\alpha$, it increases the fraction of domestic over MNBs. This implies that the effects on the structure of the banking system will be the only determinant of the level of social welfare. Indeed, we have that $\left|\frac{\partial c_{D}(\alpha)}{\partial \alpha}\right|<\left|\frac{\partial c_{\Pi}(\alpha)}{\partial \alpha}\right|$. Thus the mass of domestic banks closing down is larger compared to the new multinational banks entering the market. However the surplus generated by each MNB is the double compared to that of a domestic bank.

Figure 4 shows the relation between the resolution policy, the banking structure and the aggregate welfare.

The objective of the regulator is to choose the degree of bail-out that maximizes the social welfare:

$$
E[W(\alpha)]=\frac{1}{c_{M a x}} \int_{0}^{c_{\Pi(\alpha)}}[2 p R-2+2 \gamma-c] \mathrm{d} c+\frac{1}{c_{M a x}} \int_{c_{\Pi}(\alpha)}^{c_{D}(\alpha)}\left[p R-1+\gamma-\frac{c}{2}\right] \mathrm{d} c
$$

Hence the regulator maximizes the following function w.r.t. $\alpha$ :

$$
E[W(\alpha)] c_{M a x}=(p R-1+\gamma)\left[c_{D}(\alpha)+c_{\Pi}(\alpha)\right]-\frac{1}{4}\left[c_{D}^{2}(\alpha)+c_{\Pi}^{2}(\alpha)\right]
$$


deriving the optimal degree of bail-out:

$$
\alpha^{*}=\frac{\gamma}{\left(1-2 p+2 p^{2}\right)}>0
$$

In our simple framework the optimal resolution policy calls for a positive level of public support, given that both the numerator and the denominator in equation (25) are positive. The optimal degree of bail-out is increasing in the value of $\gamma$, that is the social value of financial services provided by banks and decreasing in the probability $p$, that is, how safe are banks.

\section{Conclusions and Future Research}

The analysis in this paper shows how the relative expected profitability of different bank business models changes when we consider different levels of public support to troubled banks. The analysis has shown that, as we reduce the scope for public funds, we might observe an increasing dominance of multinational banks. This is a relevant point, since it indicates that as a result of the new resolution framework we might see a stronger incentive for banks to internationalize, thus leading to grater financial integration. On the other hand, for low levels of bank profitability, it increases funding costs for all banks. The trade-off between the greater incentive to expand abroad, implying a greater level of diversification of banks' investments, and the increase in funding costs, which implies closure of small domestic banks, allows to identify the optimal resolution policy.

The results in our paper are consistent with the recent policy debate 4 where a diffuse opinion is that the new bail-in tool will have an impact on banks' funding costs and this might undermine the viability of smaller, less profitable banks, leading to a consolidation in the banking system.

The analysis can be extended in different ways: first, it would be interesting to introduce capital requirements: in this case we can see the interaction between the role played by ex-ante capital regulation and ex-post resolution policies. In addition, the introduction of a risk-weighted capital requirement could further expand the scope for diversification.

Another direction in which the analysis can be extended is to add heterogeneity among regulators in terms of attitudes towards public support to see the implications in terms of banking structures. In this framework it could be interesting to relax the organizational choice for a multinational bank now restricted to branches. Indeed MNB can decide to expand through subsidiaries. The alternative between branches and subsidiaries has impli-

\footnotetext{
${ }^{4}$ https://ftalphaville.ft.com/2019/01/16/1547653807000/How-much-will-it-cost-banks-to-borrow-/
} 
cations for who is the resolution authority in charge of dealing with the troubled bank. When countries have different attitudes in terms of resolution policy mix this might impact on the organizational design of the MNB. 


\section{References}

Acharya, V., Drechsler, I., and Schnabl, P. (2014). A pyrrhic victory? Bank bailouts and sovereign credit risk. The Journal of Finance, 69(6), 2689-2739.

Aldasoro, I., Hardy, B., and Jager, M. (2020). The Janus Face of bank geographic complexity. Working Papers, 858, BIS.

Arnould, G., Pancaro, C., and ?ochowski, D. (2020). Bank funding costs and solvency (No. 853). Bank of England.

Avgouleas, E., and Goodhart, C. (2015). Critical reflections on bank bail-ins. Journal of Financial Regulation, 1(1), 3-29.

Bolton, P., and Oehmke, M. (2019). Bank resolution and the structure of global banks. The Review of Financial Studies, 32(6), 2384-2421.

Calzolari, G., Colliard, J. E., and Lrnth, G. (2019). Multinational banks and supranational supervision. The review of financial studies, 32(8), 2997-3035.

Calzolari, G., and Lòrànth, G. (2011). Regulation of multinational banks: A theoretical inquiry. Journal of Financial intermediation, 20(2), 178-198.

Carletti, E., Cerasi, V., and Daltung, S. (2007). Multiple-bank lending: Diversification and free-riding in monitoring. Journal of Financial Intermediation, 16(3), 425-451.

Carletti, E., Dell?Ariccia, G., and Marquez, R. (2020). Supervisory incentives in a banking union. Management Science.

Cerutti, E., Dell'Ariccia, G., and Martnez Pera, M. S. (2005). How banks go abroad: Branches or subsidiaries?. The World Bank.

Crespi, F., Giacomini, E., and Mascia, D. V. (2019). Bail?in rules and the pricing of Italian bank bonds. European Financial Management, 25(5), 1321-1347. 
Cutura, J. (2018). Debt holder monitoring and implicit guarantees: Did the BRRD improve market discipline?. Working Paper.

Davila, E., and Walther, A. (2020). Does size matter? bailouts with large and small banks. Journal of Financial Economics, 136(1), 1-22.

Dell'Ariccia, G., and Marquez, R. (2010). Risk and the corporate structure of banks. The Journal of Finance, 65(3), 1075-1096.

Dell'Ariccia, M. G., Peria, M. M. S. M., Igan, M. D. O., Awadzi, E. A., Dobler, M., and Sandri, M. D. (2018). Trade-offs in Bank Resolution. International Monetary Fund.

Deng, S., and Elyasiani, E. (2008). Geographic diversification, bank holding company value, and risk. Journal of Money, Credit and Banking, 40(6), 1217-1238.

Dewatripont, M. (2014). European banking: Bailout, bail-in and state aid control. International Journal of Industrial Organization, 34, 37-43.

Duijm, P., and Schoenmaker, D. (2020). European banks straddling borders: risky or rewarding?. Finance Research Letters, 101525.

Faia, E., Ottaviano, G. I., and Sanchez, I. (2017). International expansion and riskiness of bank, Working Paper.

Faia, E., and Weder, B. (2016). Cross-border resolution of global banks: Bail in under single point of entry versus multiple points of entry.

Fang, Y., and van Lelyveld, I. (2014). Geographic diversification in banking. Journal of Financial Stability, 15, 172-181.

Fiordelisi, F., and Scardozzi, G. Bank Funding Strategy After the Bail-in Introduction, Working Paper.

Focarelli, D., and Pozzolo, A. F. (2005). Where do banks expand abroad? An empirical analysis. The Journal of Business, 78(6), 2435-2464. 
Freixas, X., Lrnth, G., and Morrison, A. D. (2007). Regulating financial conglomerates. Journal of Financial Intermediation, 16(4), 479-514.

Giuliana, R. (2019). Impact of Bail-In on Banks' Bond Yields and Market Discipline, Working Paper.

Goetz, M. R., Laeven, L., and Levine, R. (2016). Does the geographic expansion of banks reduce risk?. Journal of Financial Economics, 120(2), 346-362.

Harr, T., and Rønde, T. (2006). Regulation of banking groups, Working Paper, 2006/01, University of Copenhagen.

Kahn, C., and Winton, A. (2004). Moral hazard and optimal subsidiary structure for financial institutions. The Journal of Finance, 59(6), 2531-2575.

Laeven, L., and Valencia, F. (2013). Systemic banking crises database. IMF Economic Review, 61(2), 225-270.

Levine, R., Lin, C., and Xie, W. (2016). Geographic diversification and banks? funding costs, Working Paper, w22544, National Bureau of Economic Research.

Lewrick, U., Serena, J. M., and Turner, G. (2019). Believing in bail-in? Market discipline and the pricing of bail-in bonds, Working Paper.

Lintner, P., Lincoln Nagy, M. A. J., Pyziak, P., Godwin, A. J., Schroeder, S. C., and Irsalieva, N. (2016). Understanding bank recovery and resolution in the EU: a guidebook to the BRRD (No. 112266, pp. 1-182). The World Bank.

Lòrànth, G., and Morrison, A. D. (2007). Deposit insurance, capital regulations, and financial contagion in multinational banks. Journal of Business Finance and Accounting, 34(5?6), 917-949.

Luciano, E., and Wihlborg, C. (2018). Financial synergies and systemic risk in the organization of bank affiliates. Journal of Banking and Finance, 88, 208-224.

Merler, S. (2018). Bank liquidation in the European Union: clarification needed (No. 2018/01). Bruegel Policy Contribution. 
Millaruelo, A., and Del-Rio, A. (2017). The cost of interventions in the financial sector since 2008 in the EU countries. Banco de Espana Article, 9, 17.

Pablos, I. (2019). Has the new bail-in framework increased the yield spread between subordinated and senior bonds?, Working Paper.

Pandolfi, L. (2018). Bail-in vs. Bailout: a False Dilemma?, Working Paper, 499, Centre for Studies in Economics and Finance (CSEF), University of Naples.

Philippon, T., and Salord, A. (2017). Bail-ins and bank resolution in Europe. Geneva Reports on the World Economy Special Report, 4.

Schfer, A., Schnabel, I., and Weder, B. (2016). Bail-in expectations for European banks: Actions speak louder than words, Working Paper.

Walther, A., and White, L. (2019). Rules versus discretion in bank resolution. The Review of Financial Studies.

Wojcik, K. P. (2016). Bail-in in the Banking Union. Common Market L. Rev., 53, 91. 


\section{Appendix A. Case (b) when $\frac{1}{p}<R<2$}

The overall cost of funding for a MNB, solving equation (8) for $r_{M}$, can be written as:

$$
r_{M}^{b}(\alpha)=\frac{1-\alpha}{p^{2}}-\frac{(1-p)(1-\alpha) R}{p}+\alpha
$$

For coherence, we must insure that the cost of funding is greater in case (b) compared to case (a), since case (a) is the most favorable for the bank. The condition to have that $r_{M}^{a}(\alpha) \leq r_{M}^{b}(\alpha)$ is provided by assumption $\mathrm{A} 2$.

We derive the expected profit of the bank In case (b), by substituting the bond rate into (7), that is:

$$
E\left[\Pi_{M}^{b}(\alpha)\right]=c_{D}(\alpha)-2 \alpha p(1-p)(R-1)-c
$$

where $c_{D}(\alpha)$ is the threshold for the domestic bank in $(6)$.

Lemma A.1. When $R<2$, case (a) is not possible; while if $2 \leq R \leq \frac{2}{p(2-p)}$ both cases (a) and (b) are possible, but the expected profit is greater in case (a).

Proof. The result follows from the observations that:

- case (a) requires $2 r_{M}^{a}(\alpha)<R$, but since $r_{M}^{a}(\alpha)>1$ then it follows that $R \geq 2$;

- but whenever $R \geq 2$, it follows that $E\left[\Pi_{M}^{a}(\alpha)\right]>E\left[\Pi_{M}^{b}(\alpha)\right]$.

To conclude, depending on the values of $R$ we have two possible regions:

- when $R \in\left(\frac{1}{p}, 2\right)$ only case (b) is possible, therefore the expected profit is $E\left[\Pi_{M}^{b}(\alpha)\right]$;

- when $R \in\left[2, \frac{2}{p(2-p)}\right]$, case (a) is more profitable and the expected profit is $E\left[\Pi_{M}^{a}(\alpha)\right]$.

In case (b) a MNB is viable when monitoring cost is below the following threshold:

$$
c \leq \tilde{c}_{M}(\alpha) \equiv c_{D}(\alpha)-2 \alpha p(1-p)(R-1)
$$

It is immediate to see that $\tilde{c}_{M}(\alpha)$ is smaller than $c_{D}(\alpha)$.

Full bail-out. From (28) we derive the condition for a MNB to be viable with $\alpha=1$ :

$$
c \leq \tilde{c}_{M}(1) \equiv c_{D}(1)-2 p(1-p)(R-1)<c_{D}(1)
$$

and the condition for a MNB to be more profitable than a domestic bank:

$$
c \leq \tilde{c}_{\Pi}(1) \equiv c_{D}(1)-4 p(1-p)(R-1)<\tilde{c}_{M}(1)
$$


Complete bail-in. In this case investors require an interest rate that fully incorporates the risk of the different business models, that is:

$$
r_{M}^{b}(0)=\frac{1}{p}\left[\frac{1}{p}+(p R-1)\right]>r_{D}(0)=\frac{1}{p}
$$

Notice that due to the low return per unit lent, now the cost of funding is higher in the MNB case. However due to the size effect that here dominates, we still have a region where MNB are more profitable that domestic banks. Now we can derive the expected profits of the different bank models. In this case notice that all thresholds collapse to the same value:

$$
c_{D}(0)=\tilde{c}_{M}(0)=\tilde{c}_{\Pi}(0)
$$

Proposition 4. Assuming that each bank's monitoring cost is a specific realization from the uniform distribution on $\left[0, c_{M a x}\right]$, that project return $R \in\left(\frac{1}{p}, 2\right)$ occurs with probability of success $p \in(0.5,1)$ and that returns are independent across countries, we have that for any $\alpha \in[0,1]:$

(i) the MNB is more profitable than the domestic bank when $c<\tilde{c}_{\Pi}(\alpha)$;

(ii) there exists a subset of realizations of $c$ where the domestic bank is the most profitable, that is when $\tilde{c}_{\Pi}(\alpha)<c<c_{D}(\alpha)$ for any $\alpha>0$;

(iii) as the degree of public support $\alpha$ decreases, the $M N B$ becomes more profitable relatively to domestic banks; in fact, as $\alpha$ decreases, the thresholds $\tilde{c}_{\Pi}(\alpha)$ decrease less compared to $c_{D}(\alpha)$ : hence the mass of MNB increases compared to domestic banks.

Optimal resolution policy. Here we solve for the optimal degree of bail-out when $\frac{1}{p}<$ $R<2$. Maximizing (24) w.r.t. $\alpha$ replacing the threshold in case b) $\tilde{c}_{\Pi}(\alpha)$ instead of $c_{\Pi}(\alpha)$, we derive:

$$
\alpha^{*}=\frac{\gamma[1-p(R-1)]}{(1-p)\left(1-2 p(R-1)+2 p^{2}(R-1)^{2}\right)}>0
$$

